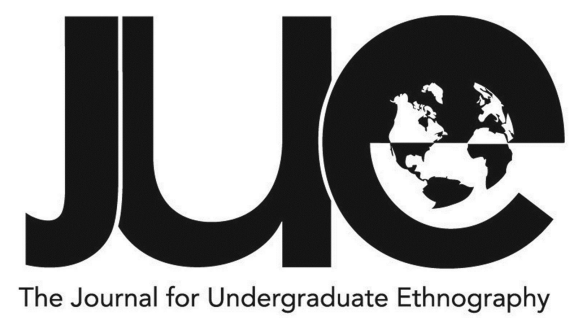

\title{
Neo-tribe Sociality in a Neoliberal World: A Case Study of Shambhala Music Festival
}

\section{Adrienne Ratushniak}

St. Francis Xavier University , adrienne.ratushniak@gmail.com

\section{ABSTRACT}

This case study of the electronic dance music (EDM) festival, Shambhala, in British Columbia, examines contemporary sociality. Both popular perception and academic discussion suggest that contemporary, neoliberal society is individualizing. In contrast, Michel Maffesoli (1996) argues that sociality is continuing but in a different form - what he refers to as a contemporary form of "neo-tribes," temporary and episodic emotional communities formed through collective interest that counteract the alienating effect of neoliberal society. This research explores those two theories, using the 2015 Shambhala Music Festival, a single location of sociality, as the case study. The results of a rapid ethnographic study conducted throughout the festival's duration in August 2015 indicate that most attendees enthusiastically confirm neo-tribalism, describing the festival as a powerful emotional "vibe" experienced collectively; sharing with and caring for each other; and a family-like "Shambhalove" among festival attendees; however, participant observation and close examination of the evidence also shows a few specific instances of neoliberal individualism. This paper explores how a community with strong neo-tribe characteristics can exist in a neoliberal capitalist context and with some attendees whose main reason for being at Shambhala is their own individual consumer gratification.

Keywords: sociality, individualism, music festivals, neo-tribe, neoliberalism 


\section{Introduction}

S ome researchers argue that with the rise of neoliberalism within capitalist society, people have become more individualized and rational (Gledhill 2004; Hayek 1944; Weber 2013). Others argue that there is increased collective sociality, which combats feelings of alienation from the general society (Maffesoli 1996). Music festivals provide a rich backdrop in which to study these theories, along with contemporary sociality in general, since many take place over several days and thereby create their own communities. I chose an electronic dance music (EDM) festival as the focus of this study because it has become an increasingly popular subculture throughout the world and, in the last few decades, a more mainstream genre of music.

The EDM subculture is particularly popular among youth populations, which for the purposes of this article include anyone under the age of thirty. While the category of "youth" is not integral to my analysis, the majority of my interviews were with participants under the age of thirty. It is interesting to note that youth exist in a liminal state. They are not children, but not quite adults either, and because of this social tension, are often prone to feelings of alienation or anomie. As Troy Glover (2003) discusses, this feeling of alienation often leads to the contemplation of personal existence and identity, which is commonly expressed through sub-cultural events and activities. Youth in particular are viewed in this way; however, some researchers posit that everyone in contemporary capitalist society is individualized and alienated (Bauman 1992; Binkley 2007).

The Shambhala Music Festival was picked as the location of my research for a variety of reasons: it takes place over four days, it is geographically accessible, and I have first-hand experience with the festival. I have attended the festival twice prior to this research, in 2013 and 2014, and my insider knowledge has given me an understanding of the festival which was useful in designing the research and proved valuable in my analysis of the data. I was aware that there is a commonly expressed notion that festival-goers find their festival experiences to affect their sense of self and I wanted to understand how that manifested itself at Shambhala. For example, the phrase "Shambhala changed my life" is frequently heard at the festival as well as on various social media forums. The language used both by the festival organizers and the festival goers evoke metaphors of community. Common words and phrases that are used to create this sense of shared community include "Shambhalove," being part of a "farm-ily" ${ }^{\prime}$ and references to Shambhala as "home." I was also aware that, besides being a mass gathering of people with a common interest, Shambhala is firmly rooted in capitalism as a commercial tourist venue that sells tickets, hires performers and sells merchandise.

The social interactions at this festival proved to be much more complex and contradictory than they appeared on the surface. Due to the self-professed connection between Shambhala and community, the evidence for collective sociality is readily apparent. The neoliberal elements are not as obvious and are not flaunted by the festival community, but they are still quite noticeable. I wanted to find out if and how collective sociality and neoliberal individualism coexist within the Shambhala Music Festival - which is why I use both neoliberal individualism and collective sociality in wider society in my study of the festival. I use Michel Maffesoli's (1996) post-modernist neotribe theory as the basis for collective sociality, which contends that neo-tribalism is pervasive throughout postmodern neoliberal society. This paper explores how a community with strong neo-tribal characteristics can exist in a neoliberal capitalist context and with some attendees whose main reason for being at Shambhala is their own individual consumer gratification. I argue that collective sociality and neoliberal individualism co-exist within the Shambhala Music Festival because there is evidence of a collective mentality, including 
acceptance of individuality, love and community, and sharing and caring, despite evidence of self-interest.

\section{Shambhala: A Festival on a Farm}

The Shambhala Music Festival is a four-day annual electronic music event that takes place every August on a working farm in the Rocky Mountains, near Salmo, British Columbia, close to the American border. The festival and the farm called the Salmo River Ranch are owned by the Bundschuh family. Shambhala began in 1998 with 500 people and local artists performing on three stages. It has grown significantly since then, with interest spreading predominantly by word of mouth. In 2015, 11,000 people attended with both local talent and internationally acclaimed DJs and producers performing on six stages along with the support of about 1,000 workers and volunteers. For the duration of the festival, Shambhala becomes the largest city in the West Kootenay region (Shambhala Music Festival 2015). Despite how popular it has become, the festival organizers' mission is to stay true to its grassroots beginning and not to accept corporate sponsorship. The organizers state that, "This mission is important to hold down as electronic dance music culture moves into the mainstream where threatened large corporations and production budgets threaten to water it down" (Shambhala Music Festival 2015).

EDM began during the late 1980s and early 1990s as a small, underground, and even deviant, subgroup of society with only a few musical subgenres. Since then it has become a mainstream music and culture conglomerate, with a multitude of different categories, styles and subgenres. As EDM has become more popular, DJs and music producers have increasingly added their own interpretations to the genre, diversifying it to the point where it has as much variety as all non-electronic music genres combined since any non-electronic genre can be remixed. For example, a remix of disco music or a song that draws heavily on disco influences is often called "nu disco" (Miller 2014). The major difference between a DJ and a music producer is that a producer creates new music while a DJ plays and remixes existing music (The DJ Podcast 2010).

In the early days of the EDM genre, there were a small number of events (typically referred to as "raves") predominantly held in major cities. Today, there are numerous multiday events around the globe devoted entirely to electronic music, some of which have become further focused on a specific EDM genre. Some of the most prominent electronic music festivals include: Tomorrowland in Belgium, Sunburn Festival in India, Rainbow Serpent Festival in Australia, Big Mountain Music Festival in Thailand, and Afrikaburn in South Africa (Fest 300 2016). There are also countless minor events like raves, DJ sets, and concerts, which have become mainstream.

\section{Fieldwork Methods at the Festival}

The research design of this project was rapid ethnography due to the short timeframe of the music festival. I arrived at the venue early in the morning on Friday, August 7, 2015 and left the following Monday afternoon. The four research methods used to collect the data are: participant observation, informal interviews, social media analysis, and photography. The informal interviews were conducted one-onone or in small groups. Most of the participants were strangers to me, but a few were people I already knew. To ensure anonymity for those I did not know, and confidentiality for those I did, I asked each participant to create a pseudonym. In total, I interviewed thirty-five people over eighteen interview sessions, both during and after the festival (see Appendix A for a full list of participants). All of the interviews were recorded and later transcribed. Rather than using letters of consent in such an informal setting and risk changing the mood, I obtained verbal consent after providing an explanation of my project, which I then documented in my field notes. The participants also received a card with my contact information in case they had any concerns after the fact. Social media analysis of the official Shambhala Facebook page, and the festival's website was used to supplement the data collected in the field. Photography, both my own and that posted on public websites, was also used to illustrate what I observed.

I chose Shambhala for my case study 
knowing I would be an insider researcher. To better understand my subjectivity, I read an article by Paul Hodkinson (2005) that looks at the pros and cons of "insider research" specifically in the study of youth cultures. In his article, Hodkinson discusses the usefulness of personal experience but stresses that it should be used selectively and with purpose. I was mindful of the cautions Hodkinson raised and felt that in my case, insider knowledge of the culture would help me gain rapport with my participants due to my knowledge of and fluency in the language used in the EDM subculture. That knowledge helped me interpret my findings more easily and analyze them in situ at the time of my observations and documentation of my field notes.

\section{Theoretical Framework: \\ Neo-tribes and Individualism}

The theoretical framework for this ethnography is two-fold, collective sociality using Maffesoli's (1996) neo-tribal theory, and neoliberal individualism. Maffesoli developed his theory to posit that despite the trend towards individualism, sociality still thrives within the postmodern, neoliberal society but it has taken on a new, neo-tribal form. While he acknowledges that neo-tribes form within a larger neoliberal capitalist society, that consideration is not the focus of his work. Within a neo-tribe the shared interests and commonalities of the community are integral. Even though these communities are temporary or cyclical, there is a strong sense of solidarity and belonging that is evoked through membership in these emotional communities (Riley et al. 2010a:355). Maffesoli argues that face-to-face interactions, what he refers to as sociality and proxemics, are an important component of neo-tribes. It is his belief that they set the foundation for the collective "we" which is the crux of sociality, and that this combination of concepts leads to "a feeling of belonging" (1996, 139) with a particular (emotional) community.

A neo-tribe as a type of social grouping is not a political organization with constant membership, typically based on things like language, geographical location, and lineage, which is what "tribal" refers to in the traditional anthropological sense of the word (Miller 2011, 162). Rather, the emphasis is on "neo" and the ephemeral nature of the community and the multiplicity of memberships. Membership in a neo-tribe is voluntary Maffesoli's neo-tribe is also similar to what Michael Warner (2002) refers to as a "public." At Shambhala the public acts as a private space for festival attendees to publicly be themselves.

Maffesoli argues that we are in a period of postmodernism with a "re-enchanted 'deindividualized' sociality" (St John 2012, 439). People are able to express their individualism safely - whatever that may mean for them while surrounded by those who are like-minded and unlikely to pass judgment. Maffesoli considers many theories of individualism invalid, as "each social actor is less acting than acted upon" (1996, 145). According to him, individualism within a neo-tribe only occurs as part of the collective community $(1996,10)$. Individualism is facilitated by the community, and likewise the community is comprised of a voluntary group of like-minded individuals.

Andy Bennett (1999) argues that Maffesoli's theory and concept of neo-tribe sociality provides an alternative framework for subcultural studies. What sets neo-tribes apart from previous subcultures like the disenfranchised hippie movement of the 1960s, or backpacker culture is that in the latter, "meaningfulness was bestowed on those who most closely approximated permanent alternative lifestyles" (Riley et al. 2010a, 357), rather than the temporary nature of a neotribal membership. Subcultural theory also tends to place the participants of any particular subgroup within a fixed demographic. In contrast, advocates for neo-tribalism emphasize the temporary, or even arbitrary, nature of neo-tribe sociality which allows for a more fluid demographic (Riley et al. 2010a, 351).

Maffesoli's (1996) book, The Time of Tribes, is an English translation of the French original with some terms deliberately not translated. Maffesoli uses the term "puissance" in his discussion on what connects people within an emotional community, as separate from the institutions of "power" (pouvoir). Maffesoli was heavily influenced by Durkheim, and 
puissance is an interpretation of “Durkheim's conceptualization of collective consciousness" (1996, x). Maffesoli's puissance refers to the "inherent energy and vital force of the people" $(1996,7)$. Puissance is a motivation for these ephemeral meetings of neo-tribes, as well as the common mentality among participants. The most common term my participants used to describe this same feeling of puissance is the "vibe."

Dance cultures exemplify the desire to be bound together. This is what Maffesoli refers to as "en reliance" and it is a central component of the neo-tribe (St John 2006, 12). People within a neo-tribe look out for one another as part of this en reliance. The notion of being bound together has been interpreted by Riley et al. as a "duty of care" among their participants (2010b, 43), a feeling of obligation to look after each other. In this sense, "bound" is different from being bound by law. Rather, it is being bound by choice since neo-tribe membership is voluntary. Therefore, the obligation is likely not done grudgingly. I use the terms 'sharing' and 'caring' to represent the en reliance concept at Shambhala because they effectively reflect the close ties that are present within this community. Sharing is largely encompassed by the gift economy that is present at this festival as well as in the larger EDM community including instances of both gifting and trading. The caring concept more resembles the duty of care used by Riley et al. where people actively make sure others are okay.

Several academics critique Maffesoli's theories. David Evans (1997) argues that Maffesoli's grand theorizing is too simplistic and fails to understand modernity as contradictory, with both uniting and individualizing tendencies (1997, 239). Where Maffesoli argues for a fundamentally de-individualized society, Evans states that neo-tribalism and individualism are not distinct. Neo-tribes depend on an individualized society where, unlike in traditional societies, people can choose (however deliberately) 'between the 'lifestyle' alternatives offered up to them by consumer capitalism" (1997, 239). He argues that there is more rational individualism occurring in the formation of these neo-tribe communities than Maffesoli acknowledges. Despite Evans's critique, he still agrees that Maffesoli's concepts can be useful for studying different pockets of society (1997, 239-240), which is what I did at Shambhala. Zygmunt Bauman (1992) also critiques Maffesoli, arguing that neo-tribes are fundamentally individualistic. He states that the sociality discussed by Maffesoli does not erode individualism, but perpetuates it, and argues for a more combined approach to the topic than the dichotomy used by Maffesoli $(1992,25)$.

These critiques lead me, and others, to the conclusion that neo-tribe theory alone is not enough to analyze effectively my case study. Following the example of Riley et al. (2010a; 2010b), I add individualism to address this need. In this article, neoliberal individualism as distinct from neo-tribal individualism is best understood as acts of self-interest, particularly evident in this case study as defiance towards or disregard for the rules and regulations at Shambhala. Within neoliberalism, self-interest takes greatest priority rather than the neo-tribal emphasis on the group or collective; it is aneveryone-for-themselves way of thinking. Bauman (2000) argues in his book, Liquid Modernity, that the individualization of society is inevitable, in contrast to Maffesoli's argument. The participants in the research done by Riley et al. (2010b), which also used a music festival as the location, demonstrate individualized self-interest, what Riley et al. call "sovereignty." This self-interest is most apparent when participants discussed the limits to which they would help others at the festival. Riley et al. note that there was a “... contradiction between 'duty of care' and 'individual choice' discourses [which] impacted on people's ability to provide support for [others]" (Riley et al. 2010b:50).

\section{Evidence of Collective Mentality: Acceptance and Individuality}

Now I use my ethnographic evidence to demonstrate the collective and neo-tribal elements of the music festival. A common sentiment about Shambhala is that the community allows everyone to be entirely themselves, at least for the duration of the festival. Uninhibited individualism is possible and even encouraged at this festival because of the acceptance of the individual and the lack of 
judgment demonstrated by the community. This expectation reinforces Maffesoli's seemingly paradoxical argument that a neotribe is a collectivity made of individuals. One of my participants, a woman with the pseudonym Candy Cane, discussed this aspect of the festival in some detail, describing the level of acceptance she has witnessed.

There's so much love here, and so much acceptance and people don't, well people judge everywhere, but I mean, for the most part, it's community. And it's where you can express yourself, and people don't judge you, you know. It doesn't matter what you believe, or where your boundaries and personal opinions are, people seem to have a little more respect and common decency here. I don't know, it's just beautiful. It's all community and love and friends. So many friends. (Candy Cane)

While Candy Cane is careful not to say there is no judgement at Shambhala, it is definitely less prominent at this festival than in everyday life.

This component of individuality is often manifested at Shambhala through decreased inhibitions, evidenced by costume choices, creativity, and behaviours. For some, Shambhala brings out an increased tolerance towards other people's expressions of individuality. This acceptance coincides with a distinct lack of individual inhibitions, the most visibly noticeable example being what people wear. Festival goers largely wear what they want - be it everyday clothing, extravagant costumes, or nothing at all. This expression of freedom connected to clothing is one of the common themes that Britz Robins, a Shambhala representative, writes about: "...you can express who you really are in a judgmentfree environment. Wearing whatever you want in public, regardless of how strange. Lying naked in the grass all weekend if you want to" (Robins 2015). There are no prescribed norms about what to wear like there are at other music events, such as cowboy boots, hats, denim and plaid at a country music festival, or all black at a gothic event. At Shambhala, it would not be unusual to see a cowboy, a Goth, and a nudist all sitting on the same blanket somewhere on the festival grounds.

Individuality within the context of Shambhala, at least for roughly a third of my participants, can be called neo-tribal because the self-expressions and self-discovery that occurs here is dependent on the community of like-minded individuals. As Maffesoli argues, this form of individualism occurs as part of the collective because it is the accepting community that enables the self-expression. Shambhala is a judgment-free community where festival goers can perform their individuality through self-discovery, creativity, costumes, and behaviours. Anything goes at Shambhala as long as no one else is being harmed. Ge-ma, a woman in her early sixties who has been coming to Shambhala for four years with her daughter Me-ma, describes the festival as "A society of non-judgmental, real energy people that just want to help and be kind" (Ge-ma).

Some of my participants discuss that Shambhala allows them to be who they want to be and others mention that Shambhala makes them more accepting of other people's individual expressions. Laniakea, who is 25 , said that she would be less comfortable with some of the behaviours and self-expressions she has witnessed at Shambhala if they occurred outside of the context of the music festival.

Last night this guy comes in my face with this like, megaphone, and he's just reciting the alphabet to me like, while I'm dancing. And I'm just like, feeling it! [laughing] Like, weird shit that in real life you would never be cool with, like "No fuck off," but here you're like "Yeah!" [laughing] It's just so funny (Laniakea).

The example above shows how the Shambhala sociality is created by both the atmosphere felt by the people who have shed their inhibitions from everyday society to be themselves and the people who acknowledge that at Shambhala they are less judgmental than in everyday life. A collective tolerance permits individuality. 


\section{Evidence of Collective Mentality: Love and Community}

Part of the collective nature at Shambhala that enables the expression of individuality is the notion of emotional energy. Puissance, Maffesoli's take on Durkheim's collective consciousness, is the inherent energy, or "vibe" of the community. Within EDM, the vibe (which is created by the crowd, the DJ/producer, and the setting) is integral to the experience. Anything that feels "off" will impact that vibe. Roughly a third of my participants talk about the collective consciousness at Shambhala in their interviews, using words like energy, vibe, and general positivity. The vibe at Shambhala is two-fold. There is the vibe of the festival in general, created by the community of festivalgoers, and there is the vibe that comes from the way in which the organizers have set the festival up. Robins describes this vibe of the festival with the concept Shambhalove: "One thing that you'll hear many Shambhala-goers talk about is a sense of connection, a certain energy, a vibe, or Shambhalove" (Robins 2015).

One of my participants, Oak Leaf, a woman in her late twenties, links the vibe and the positivity at Shambhala with a feeling of safety. "Yeah, I fell in love. Just the vibe here, it feels really safe to me... at other festivals you don't really feel like you can be alone a lot of the time... but here, I mean I hang out by myself a lot here actually. And I don't know, something about it just feels totally safe" (Oak Leaf). Along with this sentiment of safety is also a feeling of acceptance, and the ability to talk with strangers at the festival: "You can chime in on somebody else's conversation, and everybody accepts you" (Me-ma). Perhaps these feelings of safety and acceptance stream from the way that "strangers" are discussed at this festival. Rather than the ambiguous and sometimes frightening "other" that comes to mind with the word stranger, the common mentality at Shambhala is that everyone there is simply a friend you have not met yet. Robins thinks that this sentiment, that everyone at Shambhala is a friend regardless of whether you ever actually meet them or know their name, is because "most people are in an open-hearted mindset, which makes it a lot easier to meet and connect with people" (Robins 2015).
Another participant, Ursula, a 22-year-old woman, discusses a group of people that are essentially Shambhala-only friends, telling me she likely would not have been friends with them outside the context of Shambhala.

There's the people I've met at camp, like friends of friends. I never would have sought them out like, they're not the kind of people I would have befriended on my own. But, because I got to meet them in the context of Shambhala, I can see their Shambhala-selves and I haven't really seen them outside of that context. So yeah, I guess I have friends that I only see basically at Shambhala. (Ursula)

Ursula describes the "Shambhala-selves" as an important component of why she is friends with these people at Shambhala but likely would not be if this connection did not exist. Similarly, Laniakea used the words "spirit animal" and "radical" self-expression to describe how people act differently at the festival than they do in everyday life. It appears that the festival context is integral to these friendships because these people's behaviours, and Ursula's perceptions, are influenced by Shambhala. However, actually meeting at the festival is not necessarily integral to a friendship. For example, Ursula also discusses making instant friends with people in her day-to-day life after discovering they had both attended Shambhala. "Shambhala has this weird power of connection sort of. I've met a lot of people, like as soon as you find out they've been to Shambhala, they're your friend immediately. And like, obviously you're a sweet dude or sweet person" (Ursula). Another of my participants, Zenith, mentioned that he has connected with a few random strangers outside of the festival simply because Shambhala arose in conversation.

Most people attend Shambhala in small groups, but because everyone is there for the same purpose - to enjoy music - there is a connection created across the festival attendees as a whole. The following conversation between House House House and Kandi Raver ${ }^{2}$ centres on how everyone at the 
festival acts like a collective doing the exact same thing at the same time. This moment of realization has had a profound effect on them, solidifying it as a favourite memory of Shambhala.

House House House: It was this moment of, you know, the cry that goes out across the valley that travels. And there were waves of that happening and I just thought, you know, it's so amazing, there's like ten thousand people here and we're all getting ready to go dance. And that's what we're all here to do.

Kandi Raver: The realization that everyone is doing the same thing I am.

House House House: I know I know! It was amazing, so it felt, yeah, it made me feel a part of something, which was cool.

Kandi Raver: I would have to say that that night was the most magical night for me too. That first year... I just fully realized how magical this place was that night, and it's stuck with me since, it was so cool. It really was a lifechanging moment.

Like Kandi Raver and House House House, many of my participants describe moments from their first Shambhala as their favourites.

The intensity of these first-time experiences at the festival plays into creating the neotribalism that exists at Shambhala. For example, the shared experience of their first "cry" - the screaming or whooping of excitement that grows and crosses the festival grounds like a wave - is part of the magical, life-changing, and collective experience that House House House spoke about. Tim Kusnierek, a blogger, calls the often heard cry the "Shambha-wave" and describes the first time he heard it.

It's Wednesday night, and a pair of long-lost friends find each other in the mass of bodies. They scream in ecstasy and embrace one another as onlookers begin to yell and hoot along with excitement. Within seconds, hundreds of passersby add on to the joyous cacophony, and before long, thousands of people are joining in as the wave of happiness flows from the festival's downtown area all the way to the campground and back again (Kusnierek 2015).

The wave exemplifies the intense and spontaneous puissance that occurs at Shambhala. As well as hearing about it from a number of my participants, I have seen it in action. I know first-hand how infectious the wave is. It is hard not to get caught up in the excitement.

\section{Evidence of Collective Mentality: Sharing and Caring}

As discussed in the theoretical framework, Maffesoli's concept, "en reliance," describes how members of a neo-tribe are voluntarily bound together. I use the aforementioned terms, 'sharing' and 'caring'- as in sharing with, and caring for the community - to analyze what happens at Shambhala. The primary examples of sharing are indicative of the gift economy at the festival and instances of both gifting and trading occur frequently. Sharing and caring are largely intertwined because if community members did not care about each other, this type of free exchange would likely be less common. These instances of exchange occur outside of the official Shambhala market place and payment or reciprocity is not expected. On the dance floor, it is common for small items like glow sticks, stickers, or handmade items to be gifted around in return for a high-five, a hug, or even just a smile. Around the festival grounds, there are exchange posts, either tree stumps or blankets, with several small items on them and signs saying things like: "take something, leave something."

The most striking and extensive example of sharing I witnessed at the festival occurred on Sunday afternoon, the last day of the festival. A group of regular festival attendees set up a table with free fixings for peanut butter and jam 
sandwiches including dozens of bags of bread, jars of peanut butter and strawberry jam. The extent of this preparation demonstrates the forethought that went into this act. The table was set up outside the entrance to the Fractal Forest Stage located in the main area when the "Fractal Funk Jam" was playing its annual fourhour DJ collaboration. The timing and location of this act of sharing with the community makes it not only an act of sharing, but also of caring. The popularity of the Fractal Funk Jam meant the area was packed with people who had been dancing for hours and in need of nourishment. There was a steady stream of people lined up to get to the sandwich table and everywhere I went throughout the festival grounds that afternoon I saw people eating the sandwiches. This thoughtful and selfless act of feeding hundreds of strangers underscores the strength of caring that the festival-goers have for each other despite it being an episodic emotional community.

For Maffesoli, physical proximity is a key component of neo-tribes. Since a neo-tribe is an ephemeral gathering, face-to-face interactions are integral to the sociality. However, the capacity for socialization and connection via the internet has increased exponentially since Maffesoli published his theory. There are numerous social media outlets where Shambhala attendees interact with each other year-round. In these interactions, attendees reminisce about past years or share their excitement about the upcoming festival. It keeps the Shambhala vibe going. The most obvious physical interactions at Shambhala involve what I call "hug culture," as consensual hugging occurs between virtually anyone and everyone. These physical interactions occur between friends and strangers alike. Saturday night of the festival, my group ran into a couple who told us they had just gotten engaged and all nine of us fell into a spontaneous group hug of congratulations.

Caring is another important component of neo-tribal interactions and it is demonstrated in a variety of ways at Shambhala. First, caring is shown through the notion of family, or farm-ily, with Shambhala being like home. Five of my participants directly referred to Shambhala as home, or homey, during my interviews. Panther called it home when I asked her if she came every year: "I don't miss a year, it's hard not to come back home!" (Panther). Me-ma also refers to Shambhala as home after describing her first time at the festival: "We just went, with nothing. I didn't know what to expect and I've been addicted ever since. This is my home, this is where I like to be, this is my vacation time. Once a year, and I love it... I try and explain it to friends, but you don't understand until you come" (Me-ma). The festival is also called home on social media. On November 2, the same day that tickets for 2016 went on sale, the first two tiers of tickets (the Extra Early Birds and the Early Birds) sold out in a record-breaking six hours. Shambhala posted that information on their Facebook page, and one comment on it the next day was: “I'm going home!!!!!! Now gotta play the waiting game for 274 days." (Shambhala Music Festival Facebook Page, 3 November 2015, 00:43). Another commenter on that post refers to other attendees as their family: "Only goes to show you how incredible Sham is, when so many people are committing practically a year ahead of time. Can't wait to see you my family" " (Shambhala Music Festival Page, 2 November $2015,22: 58)$. This feeling of home and family, as well as the mind set that strangers are just friends you have not met yet, is reiterated by Robins in her article on common themes and sentiments about Shambhala.

Whether you're a ticket-holder or a world-class DJ, the community vibe of Shambhala stands out among festivals. On the farm, we're all "Farmily", and strangers are just friends you haven't met yet. It's a joyful reunion where you can reconnect with old friends, connect with new ones, and experience the joy and sense of belonging that goes along with being surrounded by thousands of like-minded individuals. For many, coming to Shambhala is coming Home. (Robins 2015)

The blogger Kusnierek mentions how welcomed he felt at Shambhala given that he had attended alone. He describes several different groups either helping him or "adopting" him 
throughout the weekend.

Every interaction breathed a sense of family. Since it was my first time attending, the lovely folks at will-call excitedly explained everything to me, and I was then directed to another volunteer to check in who offered to put my bags in her car, even helping me find a place to camp. I walked over to grab a meal from the delectable Curry Corner, and as I made it to the cafeteria style overhang, a group called me over to sit with them. We ended up frolicking about for the rest of the evening... On Thursday... I found a group of Canadians who adopted me into their 'Shambhafamily' for the entire weekend. Encounters like this happened on and on, each one different, yet all of them sincere and genuine (Kusnierek 2015).

Besides caring for one another in a familial way, care also has an important role in mitigating harm. The most common dangers at Shambhala are dehydration or heat stroke, as it is typically very hot during the day and festival attendees dance a lot and sleep little. Ge-ma refers to the Sanctuary, an area for psychedelic harm reduction located beside the first-aid building in the downtown area. Over-dose and drug-related harm is not common at Shambhala, but it is a real danger at all music festivals and thus important for festival-goers to look out for one another. This sentiment contrasts with the opinions of people interviewed by Riley et al. (2010b) at a different festival where the festival attendees did not exhibit the same intensity of "duty of care" that is typically exhibited at Shambhala. According to their research, the participants cared for one another only if it did not interfere with their own self-interest. My research was not on drug use, but I do look at the acts of caring that result from it. However, the bonding effect of mind altering substances would make for an interesting future study on this type of emotional community.
At Shambhala, music plays into the morning hours often until 5 a.m. or 7 a.m. depending on the stage. The later it gets, the more common it is to see people lying down on the forest floor or various seats and platforms towards the back or sides of the stages. Most often it is simply tired people taking a break from dancing, but sometimes it is a sign of a more serious problem.

The Shambhala crowd is really amazing at taking care of each other. Ask anyone who's fallen asleep near the edges of a dance floor - chances are, someone checked in on them every few minutes to make sure they were ok. This is really influenced by the culture of community, and it's heart-warming how much Shambhala attendees look out for each other. (Robins 2015)

Robins connects this act of caring with the community at Shambhala as a whole. Kit, a woman in her mid-twenties and a newbie to the festival, also talks about how heartwarming it is that everyone looks out for one another. She is a paramedic and wants to volunteer as a festival medic next year: "I want to be able to help people out if they need it... And it infiltrates all the like, guests here too. Everyone here looks out for one another. You see someone lying down and people are over there like 'Hey are you okay?!"' (Kit). I have experienced this type of caring firsthand at Shambhala. On the Saturday night of the festival, I was at one of the stages with a friend at 3:30 a.m. listening to the DJ duo Birds of Paradise. My friend was dancing, but I was getting tired so I went towards the back of the stage to lie down on a platform where I could still hear the music. Less than 30 seconds later, another festival-goer came and touched my shoulder asking me if I was okay; I just smiled and gave a thumbs up because it was loud. She smiled and went back to dancing.

Trixie, one of my participants in her late twenties, also talks about caring in our interview: "I also like how friendly everyone is, like if you're in trouble, you're not going to be in 
trouble for long cause everyone's looking out for everybody... and it's not even just the security people, it's everybody, it's festival goers, it's volunteers, it's security" (Trixie). While everyone typically looks out for one another at Shambhala, it is part of the security team's job to help people and make sure everyone is safe. Shambhala's security manager, Shaun Wilson, says he looks for people who "embody the Shambhala spirit" when hiring security workers for the festival, rather than intimidating bouncer types. Wilson looks for what he calls "the caregiver types" (Podsadzki 2014).

\section{Evidence of Neoliberal Individualism: Self-Interest}

Neoliberal individualism places self-interest above that of the group rather than being an individual as part of and because of the collective, like in neo-tribalism. Bauman argues that this neoliberalism leads to the creation of autonomous people in an individualizing society $(2000,31-32)$. In this section - which illustrates some of the ways festival attendees resist the collective, Shambhala community, thereby expressing their neoliberal individualism - I rely more on observation of the event and of media than on interviews. Most commonly, self-interest shows up as rulebreaking or frustration when there are delays or changes to the performances.

Organizers take the festival rules seriously and actively enforce them. Most notably, they do not allow glass, alcohol, or weapons on the festival grounds (Shambhala 2016a). The full list of banned items is on the festival's website and the key points are reiterated in the fine print on the back of the festival tickets. Before entry to Shambhala, tickets get verified and cars are searched thoroughly by security personnel. Security's main job is to make sure that everyone has tickets, that everyone is at least 19 years old, and that there are no banned items in the vehicle. Glass is banned at Shambhala because many people walk around the festival in bare feet and for the simple reason that for most of the year the Salmo River Ranch is a working farm: "Glass is banned to protect you, and our beloved cows, horses, ponies, donkeys and dogs" (Shambhala Music Festival 2016a). However, a lot of people sneak mirrors into the festival. According to the banned items list, only "large mirrors" are banned from the festival. Despite the rules, I know people who have had small compact mirrors confiscated in the security line after voluntarily showing them to the volunteers when asked if there are any mirrors in the vehicle. The mirrors are tagged and available for pick up after the festival.

Despite the rigour, attendees still try to sneak alcohol and glass items into the festival. As stated on their website, Shambhala is a dry event because organizers do not want this festival to be marred by the aggression that can go hand-in-hand with intoxicated people: "Over the years, we noticed something. Compared to many festivals of similar size that allow alcohol, our festival's incident rate is way lower. Not only does that make the festival safer - it creates a better vibe" (Shambhala Music Festival 2016a). Despite the fact that this festival rule is explicitly stated in multiple places, alcohol remains the most confiscated item from the security vehicle searches. Even with a thorough the security process, there are always some people who manage to sneak in alcohol.

Another example of rebellion against the rules are unauthorized sales. In the fine print on the back of the festival ticket it says, "Unauthorized commercial vending prohibited" (Shambhala Music Festival Ticket 2015) and it is clearly understood that selling anything without written consent from Shambhala Music Festival could result in being removed from the festival grounds. All the official vendors set up their wares in an area in downtown Shambhala called the Artisan Market and it fills up with food trucks, merchandise stalls (clothing, jewellery, hula hoops, etc.), and hair and make-up stylists. Anyone who wants to sell anything at the festival is required to apply for a vendor stall and meet all the requirements set by the festival. These requirements include things like minimum working hours and items allowed to be sold. Despite the threat of removal from the festival grounds, many people engage in unauthorized vending by going from campsite to campsite and walking among the tents with their merchandise like a traveling salesman.

At Shambhala 2015, a variety of people came 
by my campsite, selling things like homemade jewellery, stickers, temporary tattoos, and glow sticks. When taken at face value, these interactions can be seen as simple capitalistic opportunities. However, in the Shambhala context, they go against the regulations of the society these people have chosen to join. By deliberately engaging in these illicit activities, they are placing their own individual gain ahead of the cultural norms and ethos of the festival. The most egregious of these rogue vendors that I observed was selling gloves with lasers coming out of the fingertips. Not only was this type of sale unauthorized, handheld lasers are a prohibited item at Shambhala. The festival's website states that: "Laser pointers can very seriously damage someone's vision. We're sure that you're super careful, but we just can't take the chance of having them out there on the dance floor at eye level" (Shambhala Music Festival 2016a). This particular individual told me at my campsite that he had a stand in the Artisan Market and was selling these gloves "on the sly" because he could not sell them at his official stall. While these actions may seem benign, this person was not only deliberately breaking multiple rules of the community he has chosen to be a part of for his own monetary gain, he was also flouting a safety rule.

Besides sneaking in contraband goods and unauthorized buying and selling, frustration and dissatisfaction in general can reflect neoliberal individualism. The following conversation amongst a group of my participants exudes negativity, which is uncommon at Shambhala. This group, dissatisfied with a part of their festival experience, emphasized their personal feelings above the collective Shambhala mentality that nothing is bad or upsetting because of where you are. Jim, Party Penguin and Trixie ended up missing some of the DJs and producers that they wanted to see because of delays, which Jim refers to as "ridiculous."

Jim: On Sunday, we caught all the shows at the start and there were like, huge delays... We didn't listen to music for like, three hours. Which was ridiculous.

Party Penguin: Ugh, yeah!
Jim: just 'cuz we were hitting all the stages too early.

Trixie: Yeah, at the wrong time.

Jim: So there were these guys beat-boxing, which I was just like, "okay what?"

Trixie: Yeah, just like “let's go! Come on, I want to dance"

Party Penguin: Remember that sound check at The Grove?

Trixie: Oh, man. That was rough.

Jim: It was so long.

Party Penguin: It was brutal.

Oscar: I think all the stages were delayed on Sunday, The Village was like an hour.

Vindalicious: Yeah, by like 40 minutes. Same with The Grove, The Grove was an hour behind.

This section of this interview stood out for me because it is the only example of negativity from over sixty pages of transcriptions from my eighteen interviews. In addition, it is the sole instance of personal disappointment triumphing over the collective Shambhala experience. The rest of the interviews were overwhelmingly positive, with the overall consensus being that nothing bad could happen, or if it did it would not matter because you are at Shambhala. Despite hundreds of festival-goers being affected by the delays, this was the one and only time personal, negative feelings were mentioned. In my role as a participant observer, I witnessed some of the technical difficulties, but did not see or hear any overtly disgruntled people in the crowds. The participants in this interview had a bad experience where their individualistic wants and expectations of the music festival were not met. Ultimately, this group paid to attend a music festival, which, at least partly, failed to deliver on the last night. While I have no data to explain the reaction, I posit that the breaks in the music brought these participants back to reality before the festival ended, resulting in their obvious disappointment. As this occurred on Sunday night after I had completed most of 
my interviews, I am unaware if other people expressed similar feelings about the delays since I only conducted two interviews after the festival was over.

\section{Discussion and Conclusion}

Based on my research and my own experience, it is clear that Shambhala displays many elements of neo-tribalism. In addition to being an ephemeral, temporary mass gathering, a key aspect of neo-tribes, it is an EDM-specific music festival that has engendered strong shared interest and commonalities from its community. It has also created a strong sense of solidarity and belonging as evidenced in the language used: attendees and organizers alike describing it as "home" and people referring to themselves as part of a family or "farm-ily." Overwhelmingly, individuals are free to be themselves, surrounded by an accepting, nonjudgmental, emotional community of likeminded people. The mentality, puissance, or collective consciousness at this festival is one of positivity, inclusivity, and "Shambhalove." Instances of en reliance, voluntarily sharing with and caring for each other (friends and friends-you-have-not-met-yet alike), constitute another of the dominant characteristics of this festival. However, despite the convincing evidence supporting Shambhala as a neo-tribe, as I show in the final section of this paper, neoliberal individualism is also explicitly present at this festival. There are instances of individuals attempting, and occasionally succeeding, to get contraband items past the rigorous security measures and into the festival. This disregard for the rules and regulations determined by Shambhala, the society that these individuals have chosen to be a part of however temporarily, is an example of neoliberal individualism because it places value on personal desires and self-gratification over the values of the collective. Given the emphasis that the festival itself, and the majority of people who attend it, place on community, these examples of self-interest are more obvious than they might appear under different circumstances.

Evans (1997) suggests that neo-tribes are inherently contradictory. This contradiction was also evident in my research. While my participants may not have stressed the neoliberal characteristics of Shambhala, focusing instead on the aspects that set the festival apart from everyday life, it is still true that the relatively few instances of neoliberalism and self-serving behaviour were not enough to outweigh the emotional strength and compelling evidence of neo-tribe sociality at the 2015 festival. While these contradictions exist, it does not negate the importance of either theory. This neo-tribe does not just coexist with but thrives in a neoliberal capitalist context because of the strong shared interest in EDM and the emotional connections that are exhibited by all the participants. Shambhala is essentially a commodified leisure event while simultaneously providing a deeply significant social experience for people. Tension exists between the individual and the collective because part of the neo-tribal "vibe" is the ability to be oneself - that is, to be who you "really" are outside of the societal rules of the real world all the while being surrounded by an accepting community of like-minded people. Attendance is voluntary. People choose to spend their time and money at this festival and to experience its emphasis on community. Evans's understanding of neo-tribalism allows for a greater involvement of neoliberal individualism, so while Shambhala is not a perfect example of neo-tribe sociality as defined by Maffesoli, it still fits within a wider and more flexible neo-tribe context.

Further research is necessary to explore the contradictory nature of Shambhala, and potentially other EDM festivals, in order to understand to what degree neo-tribal and neoliberal characteristics either co-exist or dominate. Such research will identify the extent to which the predominantly youth demographic factors into the findings. It is important to note that some of my participants attend numerous EDM festivals throughout the year, while others only attend Shambhala; this is a potentially significant distinction. Further, the fact that evidence of festival attendees' responsibility to care for one another in my research at Shambhala was so drastically different from Riley et. al.'s study of a different festival requires more study to identify why and to establish which experience is more typical, 
especially since harm reduction at music festivals has become so important. It is also interesting to note that commodification is typically understood as alienating and individualizing, rather than fulfilling, like the commodification at Shambhala. 


\section{Acknowledgements}

I need to thank my Thesis Advisor, Dr. Susan Vincent, whose encouragement and guidance has been invaluable throughout the entire research process. Thank you for always pushing me, and for dedicating so much time and energy into my work. A big thank you also goes to Dr. Clare Fawcett, my second reader and the first sounding board for this research topic. To the rest of the Anthropology Department at St. FX, thank you for always providing me with advice and the motivation to work hard.

\section{Endnotes}

${ }^{1}$ Shambhala takes place on a farm.

${ }^{2 " H o u s e " ~ i s ~ a ~ g e n r e ~ o f ~ e l e c-~}$ tronic music known for its repetitive characteristic, and is House House House's favourite type of EDM. "Kandi" refers to the brightly coloured Pony Beads that are made into bracelets, masks, and other forms of apparel that are characteristic of the classic raver from the later 1990 s and early 2000s. 


\section{References}

Bauman, Zygmunt. 1992. "Survival as a Social Construct." Theory, Culture, and Society 9(1):1-36.

Bauman, Zygmunt. 2000. Liquid Modernity. Malden, MA: Polity Press.

Bennett, Andy. 1999. "Subcultures or Neo-tribes? Rethinking the Relationship between Youth, Style, and Musical Taste." Sociology 33(3):599-617.

Binkley, Sam. 2007. "Governmentality and Lifestyle Studies." Sociology Compass 1(1):111-126.

DJ Podcast. 2010. "The Difference Between a DJ and a Producer." Accessed March 15, 2016. http://thedjpodcast.com/articles/difference-dj-producer/

Evans, David. 1997. "Michel Maffesoli's Sociology of Modernity and Postmodernity: An Introduction and Critical Assessment." The Sociological Review 45(2):220-243.

Facebook. 2015 and 2016. "Shambhala Music Festival: Performance Venue." Accessed between October 27, 2015 - February 10, 2016. https://www.facebook.com/shambhalamusicfestival/?fref=ts

Fest 300. 2016. “The 300." Accessed March 15, 2016. https://www.fest300.com/worlds-best-festivals

Glover, Troy D. 2003. "Regulating the Rave Scene: Exploring the Policy Alternatives of Government." Leisure Sciences 25(4):307-325.

Hayek, Friedrich A von. 1944. The Road to Serfdom. London: Routledge.

Gledhill, John. 2004. "Neoliberalism." In Nugent D and Vincent J (eds) A Companion to the Anthropology of Politics. Maldon MA and Oxford: Blackwell Publishing Ltd., pp. 332-348.

Hodkinson, Paul. 2005. 'Insider Research' in the Study of Youth Cultures." Journal of Youth Studies 8(2):131-149.

Kusnierek, Tim. 2015. "Shambhala 2015: Is This the World's Best Music Festival?" We Got This Covered. August. Accessed February 10, 2016. http://wegotthiscovered.com/music/shambhala-worldsgreatest-festival/ 
Maffesoli, Michel. 1996. The Time of the Tribes: The Decline of Individualism in Mass Society. Translated by Rob Shields. London: Sage Publications Ltd.

Malbon, Ben. 1999. Clubbing: Dancing, Ecstasy and Vitality. London: Routledge.

Miller, Barbara. 2011. Cultural Anthropology in a Globalizing World. 3rd ed. Upper Saddle River: Pearson Education Inc.

Miller, Luke. 2014. “Everything You Ever Needed to Know about Nu Disco." The Untz. http://www.theuntz.com/news/everything-youever-needed-to-know-about-nudisco-luke-the-knifes-top-10definitive-disco-tracks/

Posadzki, Alexandra. 2014. "Taking a Trip to a Different Kind of Music Festival, For Safety's Sake." The Globe and Mail, 24 August. Accessed on 8 September 2015. http:// www.theglobeandmail.com/news/British-columbia/taking-a-tripto-a-different-kind-of-music-festival/article20081824/

Riley, Sarah, Yvette Morey, and Christine Griffin. 2010a. “The Case of 'Everyday Politics': Evaluating Neo-tribal Theory as a Way to Understand Alternative Forms of Political Participation, Using Electronic Dance Music Culture as an Example." Sociology 44 (2):345-363.

Riley, Sarah, Yvette Morey, and Christine Griffin. 2010b. “The 'Pleasure Citizen': Analyzing Partying as a Form of Social and Political Participation." Young: Nordic Journal of Youth Research 18(1): 33-54.

Robins, Britz. 2015. "10 Incredible Things You'll experience at Shambhala Music Festival." Shambhala Music Festival. March 1. Accessed February 10, 2016. http:// www.shambhalamusicfestival.com/10-incredible-things-youllexperience-at-shambhala-music-festival/

Shambhala Music Festival. 2015. "About." Accessed November 5, 2015. http://www.shambhalamusicfestival.com/about/

Shambhala Music Festival. 2016a. "Banned Items FAQ." Accessed January 20, 2016. http://www.shambhalamusicfestival.com/ banned-items-faq/

Shambhala Music Festival Ticket. 2015. Print.

St John, Graham. 2006. "Electronic Dance Music Culture and Religion: An Overview." Culture and Religion 7(1):1-20. 
St John, Graham. 2012. “Freak Media: Vibe Tribes, Sampledelic Outlaws and Israeli Psytrance." Continuum:Journal of Media and Cultural Studies 26(3):437-447.

Warner, Michael. 2002. Publics and Counterpublics. Brooklyn, NY: Zone Books.

Weber, Max. 2013. "The Spirit of Capitalism." In Social Theory: Roots and Branches, edited by Peter Kvisto, fifth edition, 74-84. Oxford: Oxford University Press.

\section{(C) $\mathcal{( \mathcal { O } \Theta \Theta}$}

This work is licensed under a Creative Commons Attribution-NonCommercialNoDerivatives

4.0 International License. 


\section{Appendix A: List of Participants}

\begin{tabular}{|c|c|c|c|c|c|}
\hline $\begin{array}{l}\text { Pseudonym and } \\
\text { interview } \\
\text { number }\end{array}$ & $\begin{array}{l}\text { Number of } \\
\text { years at } \\
\text { Shambhala }\end{array}$ & $\begin{array}{l}\text { Type of festival } \\
\text { participation }\end{array}$ & Age & Profession & Hometown \\
\hline $\begin{array}{l}\text { Karen } \\
\# 1\end{array}$ & 3 & attendee & 28 & Corporate job & Calgary, $\mathrm{AB}$ \\
\hline $\begin{array}{l}\text { Flower Kitty } \\
\# 1\end{array}$ & 4 & attendee & 23 & $\begin{array}{l}\text { International } \\
\text { recruiter for a } \\
\text { university }\end{array}$ & Calgary, AB \\
\hline $\begin{array}{l}\text { Oak Leaf } \\
\# 2\end{array}$ & 2 & attendee & 27 & Massage therapist & $\begin{array}{l}\text { New Brunswick original- } \\
\text { ly, now Banff, AB }\end{array}$ \\
\hline $\begin{array}{l}\text { Me-ma } \\
\# 3\end{array}$ & 7 & attendee & $\operatorname{mid} 30 \mathrm{~s}$ & Landscaping & Victoria, BC \\
\hline $\begin{array}{l}\text { Ge-ma } \\
\# 3\end{array}$ & 4 & attendee & $\operatorname{mid} 60 \mathrm{~s}$ & $\begin{array}{l}\text { Owner of a } \\
\text { landscaping } \\
\text { business }\end{array}$ & Victoria, BC \\
\hline $\begin{array}{l}\text { Ko Shar } \\
\# 4\end{array}$ & 1 & attendee & 26 & $\begin{array}{l}\text { Snowboard } \\
\text { instructor in } \\
\text { Whistler }\end{array}$ & Melbourne Australia \\
\hline $\begin{array}{l}\text { Bone } \\
\# 4\end{array}$ & 1 & attendee & 26 & $\begin{array}{l}\text { Snowboard instruc- } \\
\text { tor in Whistler }\end{array}$ & Melbourne Australia \\
\hline $\begin{array}{l}\text { Keystroke } \\
\# 4\end{array}$ & 1 & attendee & 25 & $\begin{array}{l}\text { Ski Instructor in } \\
\text { Whistler }\end{array}$ & Adelaide Australia \\
\hline $\begin{array}{l}\text { Google Maps } \\
\# 4\end{array}$ & 1 & attendee & 27 & $\begin{array}{l}\text { Snowboard Instruc- } \\
\text { tor in Whistler }\end{array}$ & Perth Australia \\
\hline $\begin{array}{l}\text { Sambolla } \\
\# 4\end{array}$ & 1 & attendee & 24 & $\begin{array}{l}\text { Ski instructor in } \\
\text { Whistler }\end{array}$ & Brisbane Australia \\
\hline $\begin{array}{l}\text { Wolf } \\
\# 5\end{array}$ & 1 & attendee & 21 & $\begin{array}{l}\text { Support worker in a } \\
\text { leadership develop- } \\
\text { ment organization }\end{array}$ & Kamloops, BC \\
\hline $\begin{array}{l}\text { Panther } \\
\# 5\end{array}$ & 4 & volunteer & 22 & $\begin{array}{l}\text { Partner in leader- } \\
\text { ship development } \\
\text { organization }\end{array}$ & Kamloops BC \\
\hline $\begin{array}{l}\text { Laniakea } \\
\# 6\end{array}$ & 7 & volunteer & 25 & Student & Vancouver, BC \\
\hline $\begin{array}{l}\text { Jupiter } \\
\# 7\end{array}$ & 3 & worker & $\operatorname{mid} 20 \mathrm{~s}$ & Artist & Minnesota \\
\hline $\begin{array}{l}\text { Banana Hat } \\
\text { \#8 }\end{array}$ & 1 & attendee & 20 & Moving company & Edmonton, $\mathrm{AB}$ \\
\hline $\begin{array}{l}\text { Poetess } \\
\# 9\end{array}$ & 2 & attendee & 26 & Writer and poet & Nelson, BC \\
\hline $\begin{array}{l}\text { Candy Cane } \\
\# 10\end{array}$ & 5 & attendee & 34 & Sales associate & Calgary, AB \\
\hline $\begin{array}{l}\text { Cheshire Hatter } \\
\# 11\end{array}$ & 3 & media & 21 & Marketing and film & Vancouver, BC \\
\hline
\end{tabular}




\begin{tabular}{|c|c|c|c|c|c|}
\hline $\begin{array}{l}\text { Pseudonym and } \\
\text { interview } \\
\text { number }\end{array}$ & $\begin{array}{l}\text { Number of } \\
\text { years at } \\
\text { Shambhala }\end{array}$ & $\begin{array}{l}\text { Type of festival } \\
\text { participation }\end{array}$ & Age & Profession & Hometown \\
\hline $\begin{array}{l}\text { Sage } \\
\# 11\end{array}$ & 1 & media & 20 & Journalist & Vancouver, BC \\
\hline $\begin{array}{l}\text { Anonymous } \\
\# 11\end{array}$ & 1 & media & 21 & Photographer & Unknown \\
\hline $\begin{array}{l}\text { Kandi Raver } \\
\# 12\end{array}$ & 3 & attendee & 29 & Scotiabank & Calgary, AB \\
\hline $\begin{array}{l}\text { House House } \\
\text { House } \\
\# 12\end{array}$ & 3 & attendee & 30 & $\begin{array}{l}\text { Student Affairs at } \\
\text { the University of } \\
\text { Calgary }\end{array}$ & Calgary, AB \\
\hline $\begin{array}{l}\text { Wonderland } \\
\# 13\end{array}$ & 3 & attendee & 22 & Unknown & Kelowna, BC \\
\hline $\begin{array}{l}\text { Zenith } \\
\# 13\end{array}$ & 2 & attendee & 22 & Student & Kelowna, BC \\
\hline $\begin{array}{l}\text { Mad Dabber } \\
\# 13\end{array}$ & 1 & attendee & 24 & Unknown & Kelowna, BC \\
\hline $\begin{array}{l}\text { Kit } \\
\# 14\end{array}$ & 1 & attendee & 26 & Paramedic & Northern BC \\
\hline $\begin{array}{l}\text { Mmm Bop } \\
\# 14\end{array}$ & 1 & attendee & 23 & Student & Saskatoon, SK \\
\hline $\begin{array}{l}\text { Dancing Dave } \\
\text { \#15 }\end{array}$ & 3 & worker & 41 & Carpenter & Nelson, BC \\
\hline $\begin{array}{l}\text { Ill Gates } \\
\# 16\end{array}$ & 11 & performer & $\operatorname{mid} 30 \mathrm{~s}$ & $\begin{array}{l}\text { Music producer, } \\
\text { composer, and } \\
\text { educator }\end{array}$ & $\begin{array}{l}\text { From Toronto, ON, now } \\
\text { lives in San Francisco }\end{array}$ \\
\hline $\begin{array}{l}\text { Trixie } \\
\# 17\end{array}$ & 4 & attendee & 29 & Fitness instructor & Calgary, AB \\
\hline $\begin{array}{l}\text { Jim } \\
\# 17\end{array}$ & 4 & attendee & 29 & Oil and gas & $\begin{array}{l}\text { Cornwall, ON. Now lives } \\
\text { in Calgary, } \mathrm{AB}\end{array}$ \\
\hline $\begin{array}{l}\text { Party Penguin } \\
\# 17\end{array}$ & 4 & attendee & 27 & $\begin{array}{l}\text { Sales, and audio } \\
\text { engineering }\end{array}$ & Calgary, AB \\
\hline $\begin{array}{l}\text { Vindalicious, } \\
\# 17\end{array}$ & 3 & worker & 26 & Photographer & $\begin{array}{l}\text { Calgary, AB, now lives } \\
\text { in Bristol, England }\end{array}$ \\
\hline $\begin{array}{l}\text { Oscar } \\
\# 17\end{array}$ & 2 & performer & $\operatorname{mid} 20 \mathrm{~s}$ & Music producer & Bristol, England \\
\hline $\begin{array}{l}\text { Ursula } \\
\# 18\end{array}$ & 3 & attendee & 22 & artist & $\begin{array}{l}\text { Calgary, } \mathrm{AB} \text {, now lives } \\
\text { in Vancouver, } \mathrm{BC}\end{array}$ \\
\hline
\end{tabular}

